\title{
Conference proceedings of the first international conference on mental health, March 2012
}

This article was published in the following Dove Press journal:

Journal of Parkinsonism \& Restless Legs Syndrome

26 September 2012

Number of times this article has been viewed

\section{Muhammad Tahir Khalily \\ Seema Gul \\ Uzma Masroor}

Department of Psychology, International Islamic University, Islamabad (IIUI), Pakistan
Correspondence: Muhammad Tahir Khalily Email dr.khalily@iiu.edu.pk
There has been an alarming increase in mental illness reflected in a persistent wave of violence, suicide, deliberate self-harm, and disruption in the social fabric worldwide, and particularly in Pakistan, a developing country and now the ninth most populous in the world.

Keeping in view the abovementioned mental health issues, the Department of Psychology, Faculty of Social Sciences, International Islamic University, organized the first international conference on mental health, held on March 29-30, 2012, with the theme "Violence, psychological trauma, and possible acute and post-traumatic interventions in general and particularly in Pakistani society", to enable intellectual and academic circles to acquire a profound understanding of mental health issues and develop evidence-based strategies for the amelioration of psychological ailments.

The chief invited guest at this inaugural conference was Sohail Naqvi, executive director of the Higher Education Commission, accompanied by Dr Mumtaz Ahmed, president of the International Islamic University, Islamabad, Nabi Bux Jumani, dean of the Faculty of Social Science, Muhammad Tahir Khalily, chairman and principal conference organizer, from the Department of Psychology, and Seema Gul, the coprincipal conference organizer. Tahir Khalily, the principal organizer, gave the welcome address, highlighting the prevalence of mental health problems in Pakistan as a consequence of violence. In addition, he lauded the support of the International Islamic University and Higher Education Commission in organizing this auspicious event.

Sohail Naqvi, the principal invited guest speaker, highlighted the pioneering work of the Department of Psychology, International Islamic University, for launching a BS program in psychology and promoting mental health. He also referred to the dire need to address addiction as one of our social problems, and how women can play a significant role in the resolution of these problems, including addiction.

The conference program was divided into three sessions, and each session was subdivided into presentations held in three separate rooms. Each session started with a keynote lecture from national (Murad Musa Khan, Aga Khan Medical University) and international clinical opinion leaders and academics (Inam-ul-Haq, Ireland; Grace Clark, US; Ashiq Ali Shah, Canada). Delegates were clinicians, academics, and students at the graduate, postgraduate, and doctoral levels, including professionals and scholars from different disciplines. Musa Mura Khan addressed the topic of "Challenges of suicide prevention in Pakistan". 
Table I List of presented papers

\begin{tabular}{|c|c|c|}
\hline Speaker & Presenter & Topic \\
\hline I & Zainab et al & Vicarious traumatization in adolescents \\
\hline 2 & Noor et al & Anxiety and psychological adjustment in parents of mentally retarded children \\
\hline 3 & Fatima et al & Assessing the effect of mental health on the performance of learners \\
\hline 4 & Fatima et al & $\begin{array}{l}\text { Effect of life orientation (optimism/pessimism) on mental health after controlling } \\
\text { the covariance of age, gender, and education }\end{array}$ \\
\hline 5 & Bajwa et al & Sleep patterns among medical and nonmedical students at the University of Lahore \\
\hline 6 & Naz et al & Impact of media violence exposure on aggression among adolescents \\
\hline 7 & Saleem et al & $\begin{array}{l}\text { Relationship of cumulative college grade point average and career related activities } \\
\text { with career decision making self-efficacy among female university students }\end{array}$ \\
\hline 8 & Riaz et al & Effect of economic instability on psychological health \\
\hline 9 & Bano et al & Impact of meaning in life on stress and psychological well-being \\
\hline 10 & Raza et al & Postpartum depression in primigravida women in Rawalpindi, Northern Punjab, Pakistan \\
\hline 11 & Shahzad et al & Understanding emotions in adolescents: linkage of trait emotional intelligence with aggression \\
\hline 12 & Zafar et al & Emotional intelligence and mental well-being in adolescents \\
\hline 13 & Islam et al & Effect of socioeconomic factors on mental health of women in Pakistan \\
\hline 14 & Riaz et al & Group cognitive behavioral therapy for anger management in incarcerated women \\
\hline 15 & Ambreen et al & Age and personality as moderating the relationship between social support and mental health \\
\hline 16 & Khan et al & Impression management at work place \\
\hline 17 & Wajahat, A & Childhood public masturbation in females \\
\hline 18 & Haider et al & Comparative study of different birth orders and shyness among siblings \\
\hline 19 & Riaz et al & Emotional intelligence and self esteem as determinant of subjective well-being in women \\
\hline 20 & Irum et al & Relationship between emotional intelligence and job satisfaction among teachers of special education \\
\hline 21 & Kalsoom et al & Familial social support and psychological well-being in patients with hepatitis C \\
\hline 22 & Mushtaq & Relationship between playing violent video games and aggression among children \\
\hline 23 & Hussain et al & Appalling situation of mental illness due to devastating calamities in Pakistani society \\
\hline 24 & Jahangir et al & Impact of self acceptance on life satisfaction among breast cancer women \\
\hline 25 & Hayat, I & Stressful life events, depression, and coping strategies \\
\hline 26 & Anjum et al & Neuropsychiatric sequel following traumatic brain injury: a systematic review \\
\hline 27 & Aslam, Z & Effect of Internet usage on social involvement and psychological well-being \\
\hline 28 & Awan, S & Trauma theory and post-9/II literature: the case of Pakistani and US fiction writers \\
\hline 29 & Ahmad et al & Feeling of loneliness among male and female students living in hostels \\
\hline
\end{tabular}

In total, 110 papers were presented during the conference, which was chaired by members of the scientific committee and assisted by faculty members and students of the Department of Psychology, International Islamic University. The presentations included a range of psychological/ psychiatric issues, including depression, stress, personality disorder, issues of young individuals, parenting styles, learning disabilities, emotional intelligence, violence, suicide, post-traumatic stress disorder, and adjustment problems.

The chief invited guest at the concluding ceremony, Riaz Fityana, president of the Pakistan Psychological Association and chairman of the Parliamentary Committee for Human Rights, mentioned mental health issues in his address on the current violent situation in Pakistani society. He also expressed his appreciation of the efforts of the Department of
Psychology, International Islamic University, in organizing this event and also thanked Muhammad Tahir Khalily for his kind support of the 13th National Conference of the Pakistan Psychological Association, held on November 25-26, 2011, Peshawar, Pakistan. In concluding, the principal invited guest presented shields as a token of appreciation to the organizers of the conference.

The participants and speakers appreciate the efforts of the organizing committee in promoting mental health in Pakistan. The scientific committee carefully reviewed all papers presented in the conference, and selected 29 papers (Table 1) for publication in the conference proceedings.

\section{Disclosure}

The authors have no conflicts of interest to report. 
Journal of Parkinsonism \& Restless Legs Syndrome

\section{Publish your work in this journal}

Journal of Parkinsonism and Restless Legs Syndrome is an online, open access, peer-reviewed journal. The journal publishes review articles, historical reviews, original research articles, case reports, letters to the editor, clinical teaching cases, neuroradiology highlights, neuropathology highlights, neuropsychiatry highlights, autobiographies, conference

\section{Dovepress}

proceedings, abstracts and book reviews. The manuscript management system is completely online and includes a very quick and fair peerreview system, which is all easy to use. Visit http://www.dovepress.com/ testimonials.php to read real quotes from published authors.

Submit your manuscript here: http://www.dovepress.com/journal-of-parkinsonism--restless-legs-syndrome-journal 